\title{
AGGREGATION PHEROMONE OF COCONUT RHINOCEROS BEETLE, Oryctes rhinoceros (L.) (COLEOPTERA: SCARABAEIDAE)
}

\author{
REBECCA H. HALLETT, ${ }^{1, *}$ ALICE L. PEREZ, ${ }^{2}$ GERHARD GRIES, \\ REGINE GRIES, ' HAROLD D. PIERCE JR., ${ }^{2}$ JUNMING YUE, \\ A. CAMERON OEHLSCHLAGER, ${ }^{2}$ LILLIANA M. GONZALEZ, ${ }^{3}$ and \\ JOHN H. BORDEN'
}

\author{
'Centre for Pest Management \\ Department of Biological Sciences \\ ${ }^{2}$ Department of Chemistry \\ Simon Fraser University \\ Burnaby, British Columbia, Canada V5A IS6 \\ ${ }^{3}$ Chem Tica International, Apdo 159-2150 \\ San Jose, Costa Rica
}

(Received October 31, 1994; accepted June 6, 1995)

\begin{abstract}
Male coconut rhinoceros beetles, Oryctes rhinoceros (L.), produce three sex-specific compounds, ethyl 4-methyloctanoate, ethyl 4-methylheptanoate, and 4-methyloctanoic acid, the first of which is an aggregation pheromone. Synthesis of these compounds involving conjugate addition of organocuprates to ethyl acrylate is reported. In field trapping experiments, $(4 S)$-ethyl 4-methyloctanoate and the racemic mixture were equally attractive and 10 times more effective in attracting beetles than ethyl chrysanthemumate, a previously recommended attractant. Ethyl 4-methylheptanoate was as attractive as ethyl chrysanthemumate and more attractive than 4-methyloctanoic acid, but further studies are required before it can be classed as an aggregation pheromone. Compared to ethyl 4-methyloctanoate alone, combinations of the three male-produced compounds did not increase attraction, whereas addition of freshly rotting oil palm fruit bunches to pheromone-baited traps significantly enhanced attraction. With increasing dose, captures of $O$. rhinoceros increased, but doses of 6,9 , and $18 \mathrm{mg} /$ day were competitive with $30 \mathrm{mg} /$ day lures. Newly designed vane traps were more effective in capturing beetles than were bartier or pitfall traps. Results of this study indicate that there is potential for using ethyl 4-methyloctanoate in operational programs to control $O$. rhinoceros in oil palm plantations.
\end{abstract}

*To whom correspondence should be addressed 
Key Words-Coleoptera, Scarabaeidae, Oryctes rhinoceros, coconut rhinoceros beetle, aggregation pheromone, pheromone chirality, ethyl 4-methyloctanoate, ethyl 4-methylheptanoate, 4-methyloctanoic acid.

\section{INTRODUCTION}

The coconut rhinoceros beetle, Oryctes rhinoceros (L.) (Coleoptera: Scarabaeidae), is one of the most important pests of coconut and oil palms in South and Southeast Asia (Ho and Toh, 1982; Zelazny and Alfiler, 1986). Adult rhinoceros beetles burrow into the growing point of palms and feed on unopened fronds, causing damage to inflorescences and reduction in photosynthetic area, which decreases or delays fruit production (Zelazny, 1979; Liau and Ahmad, 1991, 1993). Prolonged attacks can kill mature palms by defoliation and young palms if the growing point is destroyed. The wounds produced by the beetle provide entry points for lethal diseases and the palm weevils, Rhynchophorus ferrugineus Olivier and R. vulneratus Panzer (Bedford, 1980; Jacob and Bhumannavar, 1991).

$O$. rhinoceros breeds in decaying organic matter, such as felled rotting palms, and usually becomes a major problem in newly planted or replanted oil palm plantations. Covering the trunks with a rapidly growing ground cover (Wood, 1968) and/or shredding and burning of the felled trunks are common practices to minimize the build up of $O$. rhinoceros populations (Liau and Ahmad, 1991). Although effective, shredding and burning is very expensive and has been banned in some parts of Southeast Asia (Tajudin et al., 1993) to lower air pollution in this region of 4.5 million hectares of oil palm.

Treatment of breeding sites, such as stumps, with insecticidal drenches and routine application of granular insecticides (e.g., carbofuran) to the leaf axils of young oil palms are recommended (Ho and Toh, 1982). These techniques are currently considered economic (Liau and Ahmad, 1991) but are not very effective and present environmental and health risks. Manual removal of beetles from palms and larvae from decomposing trunks is costly and labor-intensive (Ho and Toh, 1982).

Limited success in managing $O$. rhinoceros populations has been achieved through introduction of the baculovirus, Rhabdionvirus oryctes Hüger (Bedford, 1986). Introduction of the baculovirus to the Philippines reduced $O$. rhinoceros populations to $10-20 \%$ of prerelease levels, but even low-level populations of O. rhinoceros can cause great damage (Zelazny and Alfiler, 1987, 1991). The baculovirus remains effective only if it infects new larval hosts or is repeatedly introduced, and the potential exists for $O$. rhinoceros to develop resistance to the baculovirus after prolonged exposure (Zelazny and Alfiler, 1991). Several compounds, including ethyl chrysanthemumate (EC, rhinolure) have been recommended as lures for trapping O. rhinoceros (Barber et al., 1971; Maddison 
et al., 1973; Vander Meer et al., 1979), but they are only moderately attractive (Vander Meer et al., 1979; Young, 1986).

$O$. rhinoceros adults are gregarious. More than one beetle may attack a given palm at the same time while a neighboring tree is unattacked (Gressit, 1953). Aggregation of adults in decaying palm trunks to mate and the occurrence of both single and multiple pairs of adults in the same breeding site (Zelazny and Alfiler, 1991) suggest that $O$. rhinoceros is attracted to host kairomones and employs either an aggregation or sex pheromone or both. Sex pheromones have been identified in several scarabaeids: Costelytra zealandica White (Henzell and Lowe, 1970), Popillia japonica Newman (Tumlinson et al., 1977), Kheper Lamarcki MacLeay (Burger et al., 1983), Anomala rufocuprea Motschulsky (Tamaki et al., 1985), A. cuprea Hope (Leal, 1991; Leal et al., 1993a), A. daimiana Harold (Leal et al., 1993b), A. schonfeldti Ohaus (Hasegawa et al., 1993), Blitopertha orientalis (Leal, 1993), A. octiescostata Burmeister (Leal et al., 1994a), A. albopilosa sakishimana Nomura (Leal et al., 1994b), Holotrichia parallela Motschulsky (Leal et al., 1993c), Exomala orientalis Waterhouse (Leal et al., 1994c), and A. orientalis Waterhouse (Zhang et al., 1994). An aggregation pheromone, ethyl 4-methyloctanoate, has recently been reported for Oryctes monoceros Olivier (Gries et al., 1994a).

The candidate pheromones revealed for $O$. rhinoceros are 4-methyl alkanoic acids and esters (Figure 1). Because the methyl branch of these compounds is remote from the functional group, syntheses had to be developed that allowed introduction of chirality at remote locations. The candidate pheromones were synthesized through conjugate addition of organocuprates to ethyl acrylate, which provided a shorter route to racemic 4-alkyl substituted ethyl esters than previously reported. Use of readily available enantiomers of citronellol allowed synthesis of both chiral isomers of ethyl 4-methyloctanoate.

We report the structural elucidation, synthesis, and field testing of a maleproduced aggregation pheromone and two other male-specific compounds that have the potential to be used in mass trapping of $O$. rhinoceros populations.

\section{METHODS AND MATERIALS}

Volatile Analysis and Bioassays

Larvae, pupae, or adults of $O$. rhinoceros were collected at Parungkuda, West Java, Indonesia. Fourteen female and 16 male adults were separately aerated for one week in modified Nalgene desiccators (\#5311-0250) containing sugarcane (Oehlschlager et al., 1988, 1992). A water-driven, charcoal-filtered air stream (2 liters/min) was maintained through the chambers and volatiles were captured on Porapak Q held in a glass column $(14 \mathrm{~cm}$ length $\times 13 \mathrm{~mm}$ OD). In a second series of aerations, 10 female and 10 male adults were aerated 
separately. Volatiles were eluted from the Porapak Q with $175 \mathrm{ml}$ of pentane, and the eluant was concentrated by distillation of solvent through a 30-cm Dufton column. The concentration of volatiles was adjusted so that $1 \mu \mathrm{l}$ equaled 0.6 beetle hours of production.

Porapak Q-captured volatiles from both males and females were analyzed by gas chromatographic-electroantennographic detection (GC-EAD) (Arn et al., 1975) (Hewlett Packard 5890A), utilizing a custom-built amplifier with a passive low-pass filter and a cutoff frequency of $10 \mathrm{kHz}$, and by GC analyses (Hewlett Packard 5830A) and GC-mass spectrometry (GC-MS) (Hewlett Packard 5985B), employing either a fused silica $(30 \mathrm{~m} \times 0.25 \mathrm{~mm}$ ID) or glass $(30 \mathrm{~m} \times 0.5$ mm ID) column coated with SP-1000 (Supelco, Mississauga, Ontario).

Bioassays were conducted with a white Plexiglas Y-shaped olfactometer (stem $5 \times 5 \times 20 \mathrm{~cm}$, arms $5 \times 5 \times 15 \mathrm{~cm}$ ) with a clear lid. Test compounds were added with a syringe to filter paper inside a glass cartridge placed in each arm of the olfactometer. Compressed air at $200 \mathrm{ml} / \mathrm{min}$ carried the volatiles through each arm towards beetles released singly into the stem of the olfactometer $10 \mathrm{~cm}$ from the $\mathrm{Y}$ junction. A baffle prevented mixing of the two stimuli in the $\mathrm{Y}$ junction. Beetles with intact antennae and walking ability were held $2-3 \mathrm{hr}$ in separate containers without food prior to testing. Prior to each test, the paper lining on the olfactometer floor was replaced, and beetle and position of stimuli were randomly selected. A beetle that did not move forward within 5 min of introduction was classed as a nonresponder, whereas complete entrance of a beetle into one of the arms was recorded as a response. In two experiments, $10 \mu \mathrm{l}$ of distillate from males (experiment 1) or females (experiment 2) were tested against $10 \mu \mathrm{l}$ of hexane. In order to determine behavioral activity of two synthetic male-produced compounds, a 612-ng dose of ethyl 4-methyloctanoate, 1, and ethyl 4-methylheptanoate, 3, in a 100:2 ratio was tested against $10 \mu 1$ of hexane (experiment 3 ).

\section{Instruments and General Synthetic Procedures}

Nuclear magnetic resonance (NMR) spectroscopy was conducted on a Bruker AMX-400 spectrometer at 400.13 and $100.62 \mathrm{MHz}$ for ${ }^{1} \mathrm{H}$ and ${ }^{13} \mathrm{C}$ NMR spectra, respectively. ${ }^{1} \mathrm{H}$ chemical shifts are reported relative to TMS, and ${ }^{13} \mathrm{C}$ chemical shifts are referenced to $\mathrm{CDCl}_{3}$. Gas chromatographic analyses were performed on Hewlett-Packard 5880A and 5890 instruments equipped with a flame ionization detector and a fused silica, DB-1 coated column $(15 \mathrm{~m} \times 0.25$ $\mathrm{mm}$ ID; $0.25 \mathrm{~mm}$ film) (J \& W Scientific, Folsom, California). Elemental analyses were performed using a Carbo Erba model-1106 Elemental Analyzer. Diethyl ether $\left(\mathrm{Et}_{2} \mathrm{O}\right)$ and tetrahydrofuran (THF) were freshly distilled from sodium-benzophenone-ketyl, and dichloromethane $\left(\mathrm{CH}_{2} \mathrm{Cl}_{2}\right)$ was freshly distilled from $\mathrm{CaH}_{2}$. Unless otherwise indicated, chemicals obtained from com- 
mercial sources were used without further purification. All moisture- and airsensitive reactions were conducted under argon. Column chromatography refers to flash chromatography using Silica Gel 60 (230-400 mesh, E Merck, Darmstadt, Germany) (Still et al., 1978). Thin-layer chromatography (TLC) was conducted on aluminum-backed plates precoated with Merck Silica Gel 60F-254 as the adsorbent, and visualized by treatment with an acidic solution of $1 \% \mathrm{Ce}\left(\mathrm{SO}_{4}\right)_{2}$ and $1.5 \%$ molybdic acid followed by gentle heating.

\section{Syntheses}

( \pm )-Ethyl 4-methyloctanoate (1). Compound 1 (97\% pure) (Figure 1) was synthesized as previously described (Gries et al., 1994a) or by ethyl ester formation from commercially available 4-methyloctanoic acid, 2 (CTC Organics, Atlanta, Georgia).

( \pm )-Ethyl 4-methylheptanoate (3). This compound was prepared by the conjugate addition of 2-pentyl magnesium cuprate to ethyl acrylate (Gries et al., 1994a). Compound 3 (Figure 1) was obtained as a colorless liquid (40\% yield, $95 \%$ pure). 'H NMR $\left(\mathrm{CDCl}_{3}, \mathrm{ppm}\right): 0.88(6 \mathrm{H}, \mathrm{m}) ; 1.10(1 \mathrm{H}, \mathrm{m}) ; 1.27(3 \mathrm{H}$, $\mathrm{t}, J=8 \mathrm{~Hz}) ; 1.30(2 \mathrm{H}, \mathrm{m}) ; 1.40(3 \mathrm{H}, \mathrm{m}) ; 1.66(1 \mathrm{H}, \mathrm{m}) ; 2.30(2 \mathrm{H}, \mathrm{m}) ; 4.10$

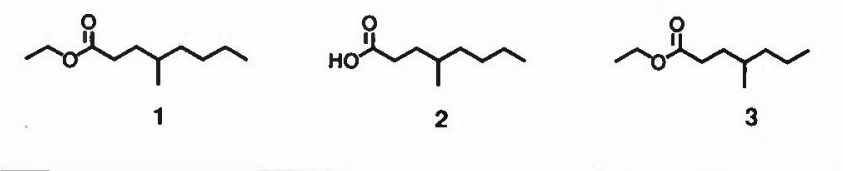

Scheme 1
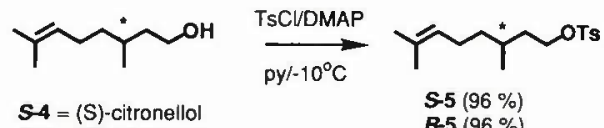
$R-4=(R)$-citronellol

S5 $(96 \%)$
$R-5(96 \%)$

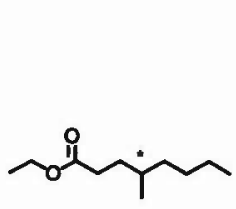

S-1 $(61 \%)$

A1 $(63 \%)$

S-6 $(90 \%)$
R-6 $(89 \%)$

FIG. 1. Compounds 1-3 and scheme for synthesis of (4S)- and (4R)-ethyl 4-methyloctanoate. 
$(2 \mathrm{H}, \mathrm{q}, J=8 \mathrm{~Hz}) ;{ }^{13} \mathrm{C}$ NMR $\left(\mathrm{CDCl}_{3}, \mathrm{ppm}\right): 174.16,60.11,36.97,32.17$ (2C), 31.95, 31.16, 19.99, 19.23, 14.23. Cl-MS m/z (relative intensity): 172 $\left(\mathrm{M}^{+}, 3\right), 127\left(\mathrm{M}^{+}-\mathrm{OEt}, 30\right), 101\left(\mathrm{M}^{+}-\mathrm{CO}_{2} \mathrm{Et}, 100\right)$.

(3S)-3,7-Dimethyl-6-octenyltosylate (S-5). Enantiomer S-5 (Figure 1, scheme 1) was prepared according to the procedure of Mori and Harashima (1993b) using $(S)$-citronellol, $S-4$ (97.5\% ee, Aldrich Chemical Co., Milwaukee, Wisconsin). Purification by column chromatography $\left(9: 1\right.$, pentane $/ \mathrm{Et}_{2} \mathrm{O}$ as eluant) yielded $5.70 \mathrm{~g}$ of $S-5,(96 \%$ yield, $98 \%$ pure) as a pale yellow oil; ${ }^{1} \mathrm{H}$ NMR $\left(\mathrm{CDCl}_{3}, \mathrm{ppm}\right): 0.80(3 \mathrm{H}, \mathrm{d}, J=8.8 \mathrm{~Hz}) ; 1.10(1 \mathrm{H}, \mathrm{m}) ; 1.20(1 \mathrm{H}$, $\mathrm{m}) ; 1.40(1 \mathrm{H}, \mathrm{m}) ; 1.50(1 \mathrm{H}, \mathrm{m}) ; 1.52(1 \mathrm{H}, \mathrm{m}) ; 1.56(3 \mathrm{H}, \mathrm{s}) ; 1.70(3 \mathrm{H}, \mathrm{s})$; $1.90(2 \mathrm{H}, \mathrm{m}) ; 2.45(3 \mathrm{H}, \mathrm{s}), 4.02(2 \mathrm{H}, \mathrm{m}) ; 5.0(1 \mathrm{H}, \mathrm{t}, J=8.8 \mathrm{~Hz}) ; 7.32(2 \mathrm{H}$, $\mathrm{d}, J=8.8 \mathrm{~Hz}) ; 7.80(2 \mathrm{H}, \mathrm{d}, J=8.8 \mathrm{~Hz}) ;{ }^{13} \mathrm{C} \mathrm{NMR}\left(\mathrm{CDCl}_{3}, \mathrm{ppm}\right): 144.60$, $133.41,131.44,129.79,127.88,124.34,69.05,36.72,35.69,28.93,25.66$, 25.27, 21.60, 19.06, 17.60; Cl-MS $\mathrm{m} / \mathrm{z}$ (relative intensity): $310\left(\mathrm{M}^{+}, 2\right), 138$ $\left(\mathrm{M}^{+}-\mathrm{OSO}_{2}-\mathrm{C}_{6} \mathrm{H}_{4}-\mathrm{CH}_{3}, 50\right) . \boldsymbol{R}-5$ [from $(R)$-citronellol; $96 \%$ ee]: $5.61 \mathrm{~g}, 96 \%$ yield ( $98 \%$ pure).

$(6 R)$-2,6-Dimethyl-2-decene $(\boldsymbol{R}-\mathbf{6})$. This intermediate compound was prepared according to the procedure of Fouquet and Schlosser (1974). CuCN (Aldrich Chemical Co.) was used as received. Column chromatography (pentane) afforded $2.42 \mathrm{~g}$ ( $89 \%$ yield, $97 \%$ pure) of $\boldsymbol{R}-\mathbf{6}$ as a coloriess liquid. 'H NMR $\left(\mathrm{CDCl}_{3}, \mathrm{ppm}\right): 0.88(3 \mathrm{H}, \mathrm{d}, J=7.3 \mathrm{~Hz}) ; 0.90(3 \mathrm{H}, \mathrm{t}, J=7.3 \mathrm{~Hz}) ; 1.10(2 \mathrm{H}$, $\mathrm{m}) ; 1.30(7 \mathrm{H}, \mathrm{m}) ; 1.60(3 \mathrm{H}, \mathrm{s}) ; 1.70(3 \mathrm{H}, \mathrm{s}) ; 1.90(2 \mathrm{H}, \mathrm{m}) ; 5.1(1 \mathrm{H}, \mathrm{t}, J=$ $8 \mathrm{~Hz}) ;{ }^{13} \mathrm{C} \mathrm{NMR}\left(\mathrm{CDCl}_{3}, \mathrm{ppm}\right): 130.83,125.16,37.19,36.68,32.46,29.29$, 25.62 (2C), 23.01, 19.60, 17.55, 14.05. Cl-MS $\mathrm{m} / \mathrm{z}$ (relative intensity): 168 $\left(\mathrm{M}^{+}, 40\right)$; IR (neat): 2926, 1673, 1458, 1377, 1122, 1094, 984, $826 \mathrm{~cm}^{-1}$. Anal. calcd. for $\mathrm{C}_{12} \mathrm{H}_{24}: \mathrm{C}, 85.63 ; \mathrm{H}, 14.37$. Found: C, 85.69; H, 14.30 . S-6: $2.39 \mathrm{~g}, 90 \%$ yield ( $98 \%$ pure). Anal. calcd. for $\mathrm{C}_{12} \mathrm{H}_{24}: \mathrm{C}, 85.63, \mathrm{H}$; 14.37. Found: C, $85.78 ; \mathrm{H}, 14.57$.

(4R)-Methyloctanal $(\boldsymbol{R}-7)$. Compound $\boldsymbol{R}-\mathbf{7}$ was prepared according to the procedure of Mori and Harashima (1993a). Column chromatography $(8: 2$, pentane/Et ${ }_{2} \mathrm{O}$ as eluant, TLC $\left.\boldsymbol{R}_{f}=0.55\right)$ afforded $\boldsymbol{R}-7(1.68 \mathrm{~g}, 87 \%$ yield, $96 \%$ pure) as a colorless liquid. 'H NMR $\left(\mathrm{CDCl}_{3}, \mathrm{ppm}\right): 0.90(6 \mathrm{H}, \mathrm{m}) ; 1.12(1 \mathrm{H}$, $\mathrm{m}) ; 1.30(5 \mathrm{H}, \mathrm{m}) ; 1.40(2 \mathrm{H}, \mathrm{m}) ; 1.64(1 \mathrm{H}, \mathrm{m}) ; 2.64(2 \mathrm{H}, \mathrm{m}) ; 9.75(1 \mathrm{H}, \mathrm{s})$; ${ }^{13} \mathrm{C} \mathrm{NMR}\left(\mathrm{CDCl}_{3}, \mathrm{ppm}\right): 202.87,41.70,36.36,32.38,29.16,28.93,22.91$, 19.35, 14.05; Cl-MS $m / z$ (relative intensity): $143\left(\mathrm{M}^{+}+1,100\right)$; IR (neat): $2927,2715,1727,1465,1379,1263,1133,1012,896,849,729 \mathrm{~cm}^{-1}$. Anal. calcd. for $\mathrm{C}_{9} \mathrm{H}_{18} \mathrm{O}$ : C, 75.00; H, 12.76. Found: C, 75.09; H, 12.48. S-7: 1.65 g, $85 \%$ yield ( $98 \%$ pure). Anal. calcd. for $\mathrm{C}_{9} \mathrm{H}_{18} \mathrm{O}: \mathrm{C}, 75.00 ; \mathrm{H}, 12.76$. Found: C, $74.98 ; \mathrm{H}, 12.66$.

(4R)-4-Methyloctanoic acid ( $\boldsymbol{R}-2)$. This compound was prepared by the oxidation of $\boldsymbol{R - 7}$ (yield $1.78 \mathrm{~g}$ ) according to the procedure of Furniss et al. 
(1989). Compound $\boldsymbol{R}-\mathbf{2}$ was used for the next step without further purification. ${ }^{1} \mathrm{H} \mathrm{NMR}\left(\mathrm{CDCl}_{3}, \mathrm{ppm}\right): 0.90(6 \mathrm{H}, \mathrm{m}): 1.12(1 \mathrm{H}, \mathrm{m}) ; 1.14(5 \mathrm{H}, \mathrm{m}) ; 1.60(2 \mathrm{H}$, $\mathrm{m}) ; 1.80(1 \mathrm{H}, \mathrm{m}) ; 2.35(2 \mathrm{H}, \mathrm{m}), 11.30(1 \mathrm{H}$, br. s). $S-2: 1.45 \mathrm{~g}$.

(4R)-Ethyl-4-methyloctanoate $(\boldsymbol{R}-1)$. Enantiomer $\boldsymbol{R}-2$ was esterified using the Fisher method (Furniss et al., 1989). Column chromatography (9:1, pentane/Et ${ }_{2} \mathrm{O}$ as eluant) gave $1.34 \mathrm{~g}$ of $\boldsymbol{R}-\mathbf{1}$ ( $61 \%$ yield based on $\boldsymbol{R}-7,98 \%$ pure). $[\alpha]_{\mathrm{D}}^{20}=-1.67^{\circ}\left(c=1.345, \mathrm{CHCl}_{3}\right) ;{ }^{1} \mathrm{H} \mathrm{NMR}\left(\mathrm{CDCl}_{3}, \mathrm{ppm}\right): 0.88(3 \mathrm{H}, \mathrm{d}$, $J=8 \mathrm{~Hz}) ; 0.90(3 \mathrm{H}, \mathrm{t}, J=8 \mathrm{~Hz}) ; 1.10(1 \mathrm{H}, \mathrm{m}) ; 1.24(3 \mathrm{H}, \mathrm{t}, J=8 \mathrm{~Hz})$; $1.30(5 \mathrm{H}, \mathrm{m}) ; 1.40(2 \mathrm{H}, \mathrm{m}) ; 1.66(1 \mathrm{H}, \mathrm{m}) ; 2.30(2 \mathrm{H}, \mathrm{m}) ; 4.10(2 \mathrm{H}, \mathrm{q}, J=$ $8 \mathrm{~Hz}) ;{ }^{13} \mathrm{C}$ NMR $\left(\mathrm{CDCl}_{3}, \mathrm{ppm}\right): 174.12,60.14,36.36,34.42,32.21,31.97$, 29.17, 22.94, 19.31, 14.25, 14.06; IR (neat): 2958, 2884, 1737, 1461, 1373, $1261,1173,1108,1032,932,855,779,732 \mathrm{~cm}^{-1}$. Anal. calcd. for $\mathrm{C}_{11} \mathrm{H}_{22} \mathrm{O}_{2}$ : C, 70.91; H, 11.91. Found: C, 70.99; H, 12.00. S-1: $1.36 \mathrm{~g}, 63 \%$ yield based on $S-7$ (98\% pure) $[\alpha]_{\mathrm{D}}^{20}=+1.67^{\circ}\left(c=1.350, \mathrm{CHCl}_{3}\right)$. Anal. calcd. for $\mathrm{C}_{11} \mathrm{H}_{22} \mathrm{O}_{2}: \mathrm{C}, 70.91 ; \mathrm{H}, 11.91$. Found: $\mathrm{C}, 70.82 ; \mathrm{H}, 11.98$

\section{Chiral Determination}

Enantiomeric excess of $(R)$ - and $(S)$-citronellol was determined through GC analysis (DB-1) as the amides of D- $(+)$ - $\alpha$-phenylethylamine (Sigma, St. Louis, Missouri) of the corresponding citronellic acids (Sonnet and Gazzillo, 1990).

Analysis of $S-\mathbf{1}$ and $\boldsymbol{R}-\mathbf{1}$ by GC on a fused silica, Cyclodex-B-coated column $(30 \mathrm{~m} \times 0.25 \mathrm{~mm}$ ID, J \& W Scientific) failed to resolve the enantiomers. 'H NMR spectra in the presence of tris[3-(heptanofluoropropylhydroxymethy]ene)-(-)-camphorato]europium(III) $\left[\mathrm{Eu}(\mathrm{hfc})_{3}\right]$ in $\mathrm{CS}_{2}(1: 1$ or $1: 2$ ratio, ester: shift reagent) (McCreary et al., 1974; Valentine et al., 1976) or the chiral solvating agent $(R)$-2,2,2-trifluoro-1-(9-anthryl)ethanol in $\mathrm{CCl}_{4}(1: 1$ or $1: 2$ ratio, ester: anthrylethanol) (Pirkle et al., 1977; Pirkle and Sikkenga, 1977) failed to display diastereoisomeric complexes at different chemical shifts.

\section{Field Experiments}

Experiments were conducted in 1- or 2-year-old oil palm plantings at three P.T.P.P. London Sumatra Indonesia estates in North Sumatra, Indonesia. Specific locations are given either in Figures 5-10 below or in the text, if data are not presented in figures. All experiments were set up as randomized complete blocks with intertrap and interblock distances of at least 27 and $54 \mathrm{~m}$, respectively. Traps were checked daily and captured beetles removed.

All compounds, except $S-1$ and $R-1$, were released from heat-sealed, polymer membrane bag devices (Chem Tica International, Costa Rica) at constant rates. Release rates for each compound were determined by placing 10 sealed 
devices containing $1 \mathrm{ml}$ of neat compound in a thermostated chamber ( $25 \pm$ $1{ }^{\circ} \mathrm{C}, 60 \%$ relative humidity), allowing $48 \mathrm{hr}$ equilibration, and then weighing $( \pm 0.1 \mathrm{mg}$ ) each device every two to three days for two weeks (devices releasing $30 \mathrm{mg} /$ day) or four to five weeks (devices releasing $<30 \mathrm{mg} /$ day). Variability of release rates between devices was $< \pm 5 \%$ and over the measurement period was $< \pm 10 \%$. Compound 1 was released at $0.9,3,6,9$, and $30 \mathrm{mg} /$ day; 2 at 3 and $15 \mathrm{mg} /$ day; 3 at 1 and $30 \mathrm{mg} /$ day; and EC at $15 \mathrm{mg} /$ day. Combinations of devices were used to achieve some release rates. $S-1$ and $R-1$ were released at $0.3 \mathrm{mg} /$ day (at $25^{\circ} \mathrm{C}$ ) from $1-\mathrm{mm}-\mathrm{ID}$ glass capillary tubes cut $1 \mathrm{~cm}$ above the meniscus and placed in capped $400-\mu 1$ plastic centrifuge tubes with two 3-mm holes $1 \mathrm{~cm}$ below the top.

\section{Behavioral Activity of Ethyl 4-methyloctanoate}

A three-treatment, 10-replicate experiment (experiment 4) determined activity of the candidate pheromone, $\mathbf{1}$. Black pitfall traps (Figure 2) were buried in the ground $1-1.5 \mathrm{~m}$ from palms and baited with either decomposing oil palm tissue (1-2 kg of leaf bases or empty fruit bunches), 1 (released at $30 \mathrm{mg}$ per day), or both. Oil palm tissue or a cloth placed in traps baited with 1 only, was treated with $0.3 \%$ active ingredient solution of Basudin $60 \mathrm{EC}$ (diazinon, Ciba-

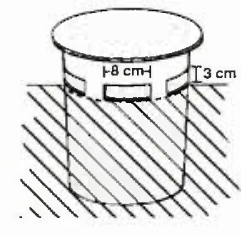

Pitfall Trap
Barrier Trap

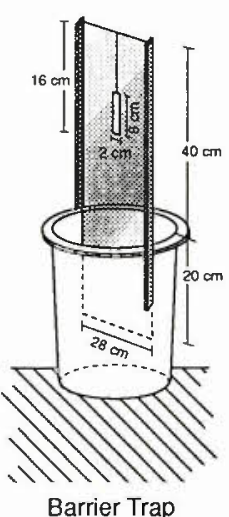

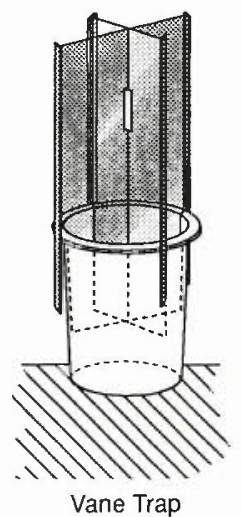

Vane Trap
FIG. 2. Trap designs used for capturing $O$. rhinoceros. Pitfall trap: 19-liter black bucket buried in ground to allow beetles to enter through slots below rim; pheromone lure suspended within bucket from plywood lid. Barrier and vane traps: 20-liter white bucket with one or two unpainted sheet metal vanes extending $20 \mathrm{~cm}$ into bucket to prevent beetles from flying out; wooden slats on edge of vanes for reinforcement; lures suspended within slot to allow volatile dissemination in all directions. 
Geigy). Beetles were captured because of contact with the insecticide-treated substrate or inability to exit the traps.

\section{Trap Design Experiments}

A three-treatment, 10-replicate experiment (experiment 5) compared trapping efficacies of pitfall to barrier and vane traps (Figure 2). In experiment 6 $(N=9)$, four types of vane traps were compared: unpainted (standard) vane traps (Figure 2), vane traps fitted with an internal funnel (15 $\mathrm{cm}$ opening) to prevent beetle escape, traps with matte black-painted vanes, and traps with both funnels and black-painted vanes (Dolok Estate, February 26-March 11, 1994). In both experiments 5 and 6 , traps were baited with lures releasing 1 at $30 \mathrm{mg} /$ day. No insecticide or organic matter was used in any of the traps.

\section{Dose-Response of Ethyl 4-methyloctanoate}

In a four-treatment, 18-replicate experiment (experiment 7) with standard vane traps at $36 \mathrm{~m}$ intervals, 1 was released at $0,0.3,3$, or $30 \mathrm{mg} /$ day. In experiment $8(N=15)$, standard vane traps were baited with 1 released at 0 , $3,6,9$, or $30 \mathrm{mg} /$ day. In experiment $9(N=12)$, standard vane traps were baited with 1 released at $0,6,9,18$, or $30 \mathrm{mg} /$ day. To minimize interference between treatments in experiments 8 and 9 , intertrap and interblock distances were increased to 54 and $\geq 63 \mathrm{~m}$, respectively.

\section{Chiral Isomers of Ethyl 4-methyloctanoate}

A four-treatment, 10-replicate experiment (experiment 10) tested attraction of beetles to racemic $\mathbf{1}, S-\mathbf{1}, \boldsymbol{R}-\mathbf{1}$, or a blank control in standard vane traps. $S$ - or $\boldsymbol{R}-1$ were released at $\sim 2 \mathrm{mg} /$ day from eight capillary tubes and racemic 1 was released at $\sim 4 \mathrm{mg} /$ day from 16 capillary tubes.

\section{Other Candidate Pheromones and Attractants}

Attraction of beetles to three male-produced compounds, 1, 2, 3, and to $( \pm$ )-ethyl chrysanthemumate (EC, $95 \%$ pure, mixture of cis and trans, Aldrich Chemical Co.) was compared in experiment $11(N=10)$. All compounds were released at $30 \mathrm{mg} /$ day. Experiment $12(N=9)$ compared attraction of beetles to 1 alone ( $30 \mathrm{mg} /$ day) and in combination with 3 at ratios of $100: 1,100: 10$, and 100:100 (Rambong Sialang Estate, April 13-21, 1994). Experiment 13 $(N=10)$ compared attraction of beetles to 1 alone $(10 \mathrm{mg} /$ day $)$ or in approximate natural ratios with either or both of 2 (30 mg/day) and $3(0.1 \mathrm{mg} /$ day) (Rambong Sialang Estate, June 9-17, 1994). 


\section{Pheromone-Host Material Interactions}

The attraction of beetles to 1 ( $9 \mathrm{mg} /$ day) alone, freshly milled empty fruit bunches $(1 / 3$ to $1 / 2$ bunch per trap), or to both was examined in a three-treatment, 12-replicate experiment (experiment 14).

\section{Statistical Analyses}

The proportions of beetles responding to each stimulus in laboratory bioassays were compared by using the normal approximation to the binomial test, and differences between responses of female and male beetles were compared with $\chi^{2}$ tests (Zar, 1984).

In all field experiments, no significant differences were found in the responses of male and female beetles and so catches were pooled by sex for analysis. Data were transformed by $\log (x+1)$ if they were not normally distributed and were subjected to analysis of variance (general linear modeling) (Minitab, 1989). If replicates were run at different times or locations, data were analyzed for time $\times$ treatment or location $\times$ treatment interactions. Following ANOVA, multiple pair comparisons were made using Bonferroni $t$ tests. If homoscedasticity was not achieved by transformation, data were analyzed by $\chi^{2}$ tests (Zar, 1984).

\section{RESULTS}

GC and GC-EAD analyses of Porapak Q-trapped volatiles obtained from aerations of either $O$. rhinoceros males or females revealed two abundant malespecific components (Figure 3), of which the early eluting volatile elicited antennal responses by male and female antennae (Figure 4). Retention and mass spectrometric characteristics of these two compounds were identical to ethyl 4-methyloctanoate, 1, and 4-methyloctanoic acid, 2. A second EAD-active compound (not visible in Figure 4) had a Kovats retention index ( RI $=1379)$ suggestive of ethyl 4-methylheptanoate, 3. GC-MS in both electron impact and chemical ionization modes of beetle-produced and authentic $\mathbf{3}$ confirmed this structural assignment.

In laboratory bioassays (experiments 1 and 2), male-produced volatiles were equally attractive to walking male and female $O$. rhinoceros, but femaleproduced volatiles were attractive only to males (Table 1). Behavioral activity of synthetic 1 plus 3 was demonstrated in experiment 3 (Table 2) and justified field testing of synthetic candidate pheromones. In field experiments, 1 at 30 $\mathrm{mg} /$ day alone or in combination with decomposing palm tissue attracted more beetles than palm tissue alone (Figure 5 ; experiment 4 ).

Both vane and barrier traps were superior to the pitfall trap (Figure 2), with 

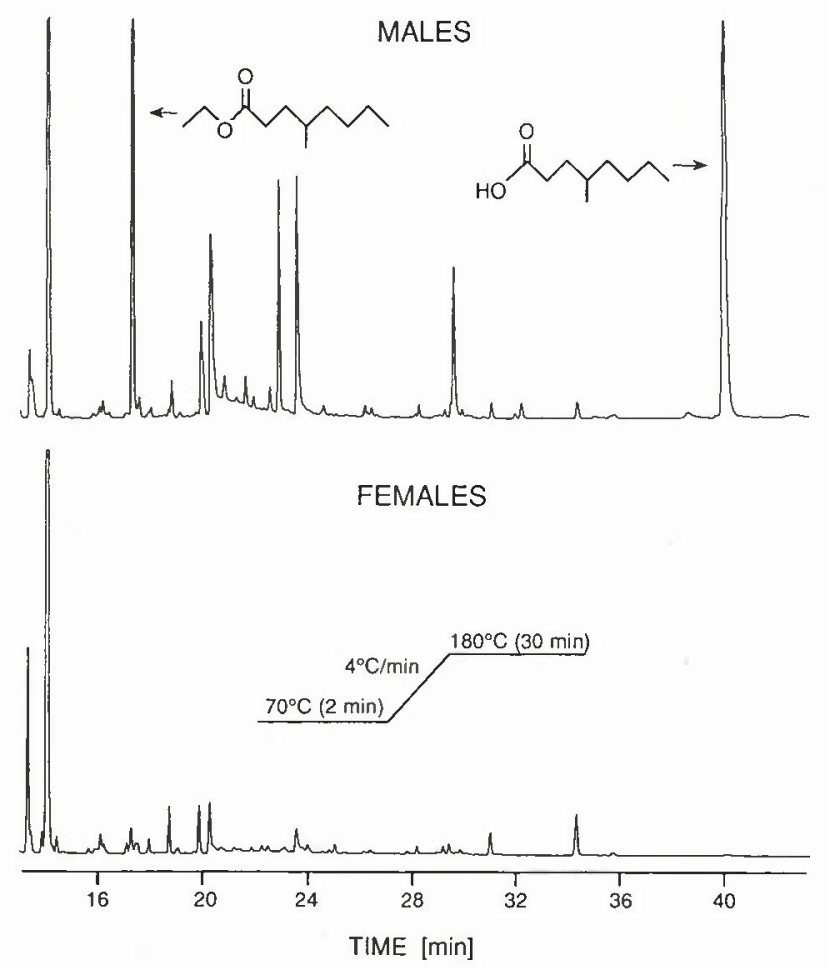

FIG. 3. Gas chromatograms of volatiles from 10 male and 10 female $O$. rhinoceros maintained in aeration chambers for one week with provision of sugarcane as food source. Chromatography: Hewlett Packard 5830A gas chromatograph (GC) equipped with a glass capillary column $(30 \mathrm{~m} \times 0.5 \mathrm{~mm}$ ID) coated with SP-1000.

vane traps capturing about three times more beetles than pitfall traps (Figure 6; experiment 5). Addition of a funnel to the vane trap and painting vanes black did not alter trap efficacy (experiment 6; ANOVA, $F=1.19, d f=3, P=$ 0.341 ).

Catches of $O$. rhinoceros increased with increasing release rates of the pheromone (Figure 7; experiments 7-9). A significant location $\times$ dose interaction was observed in experiment $7(F=18.39, d f=1, P<0.001)$, which arose from the $3 \mathrm{mg} /$ day lure being more attractive relative to the $30 \mathrm{mg} /$ day lure at Rambong Sialang than at Dolok (mean catches in $3 \mathrm{mg} /$ day traps were $64 \%$ and $32 \%$ of those in $30 \mathrm{mg} /$ day traps, respectively). This result along with the prohibitive cost of $30 \mathrm{mg} /$ day lures, prompted us to examine release rates between 3 and $30 \mathrm{mg} /$ day. In experiments 8 and 9 , lures releasing 1 at 6,9 , and $18 \mathrm{mg} /$ day were competitive with $30 \mathrm{mg} /$ day lures (Figure 7). 


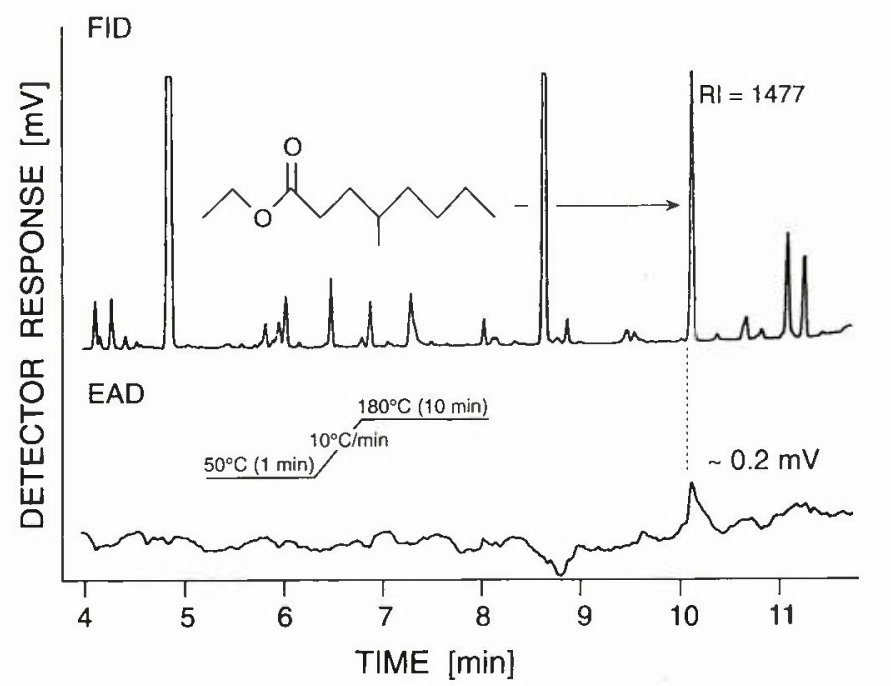

FIG. 4. FID and EAD responses to volatiles obtained from male $O$. rhinoceros. The antennal recording was carried out with an antenna of a female beetle. Chromatography: Hewlett Packard (HP) 5890A gas chromatograph (GC) equipped with a fused silica column $(30 \mathrm{~m} \times 0.25 \mathrm{~mm}$ ID) coated with SP-1000.

Racemic $\mathbf{1}$ and $S-\mathbf{1}$ were superior to $\boldsymbol{R} \mathbf{- 1}$ in attracting beetles (Figure 8; experiment 10). Racemic 1 was significantly more attractive than 2,3 , or EC (Figure 9; experiment 11); 3 was significantly more attractive than 2, but both compounds did not differ in attraction from EC. Traps baited with 1 alone or with 3 in different ratios were equally attractive (experiment 12; ANOVA, $F=$ $0.49, d f=3, P=0.693$ ), as were traps baited with 1 alone, 1 plus 2 , or 1 plus 2 and 3 (experiment 13; ANOVA, $F=2.28, d f=3, P=0.105$ ).

Freshly milled oil palm fruit bunches alone were unattractive to rhinoceros beetles, but in combination with 1 they significantly enhanced pheromonal activity (Figure 10; experiment 14).

\section{DISCUSSION}

Methyl-branch-substituted pheromones are very common (Mori, 1992). There are several synthetic methods described for the synthesis of 4-methyl alkanoic acids and esters. Compounds 1 and $\mathbf{3}$ were prepared by Cason et al. (1944) by reaction of ethyl levulinate or levulinic acid with the corresponding Grignard reagent to produce a $\gamma, \gamma$-dialkylbutyrolactone. Treatment of the lactone with $\mathrm{SOCl}_{2} /$ ethanol $/ \mathrm{HCl}$ followed by hydrogenation produced the respec- 
Table 1. Responses of Male and Female Oryctes rhinoceros Tested Individually to Pentane Extract of Male- and Female-Produced Volatiles $(10 \mu \mathrm{l}=5.6$ Beetle Hours) versus $10 \mu \mathrm{l}$ of Hexane Control in Y-Shaped Olfactometer

\begin{tabular}{|c|c|c|c|c|c|}
\hline \multirow[b]{2}{*}{ Experiment } & \multirow[b]{2}{*}{ Sex } & \multirow[b]{2}{*}{$\mathrm{n}$} & \multicolumn{2}{|c|}{ Number of responders to stimuli" } & \multirow[b]{2}{*}{$P^{\prime \prime}$} \\
\hline & & & Extract & Control & \\
\hline \multirow{2}{*}{$\begin{array}{l}\text { 1. Female extract } \\
\text { versus hexane } \\
\text { control }\end{array}$} & Male & 20 & 9 & 2 & 0.006 \\
\hline & Female & 20 & 5 & 8 & 0.393 \\
\hline \multirow{2}{*}{$\begin{array}{l}\text { 2. Male extract } \\
\text { versus hexane } \\
\text { control }\end{array}$} & Male & 15 & 12 & 1 & 0.0001 \\
\hline & Female & 17 & 13 & 3 & 0.0014 \\
\hline
\end{tabular}

"Responses to female extract in experiment 1 differ between males and females, $\chi^{2}=4.608, d f=1, P=0.032$. Responses to male extract in experiment

2 are not significantly different between males and females, $\chi^{2}=0.738, d f=1, P=0.39$

${ }^{b}$ Determined by normal approximation to the binomial test (Zar, 1984). 
Table 2. Responses of Male and Female Oryctes rhinoceros Tested INDIVIDUALLY TO $612 \mathrm{ng}$ OF 100:2 BLEND OF SyNTHETIC ETHYL 4-Methyloctanoate (1) and Ethyl 4-Methylheptanoate (3) versus $10 \mu \mathrm{l}$ OF Hexane Control in Y-Shaped OlFaCtOMETER (EXPERIMENT 3)

\begin{tabular}{lcccc}
\hline & & \multicolumn{2}{c}{ Number of responders to stimuli } \\
\cline { 3 - 5 } Sex tested & $N$ & Synthetic blend & Hexane control & $P^{b}$ \\
\hline Male & 29 & 17 & 7 & 0.025 \\
Female & 29 & 19 & 7 & 0.008 \\
\hline
\end{tabular}

"Responses are not significantly different between males and females, $\chi^{2}=0.031, d f=1, P=$ 0.86 .

${ }^{\text {h}}$ Determined by normal approximation to the binomial test (Zar, 1984).

tive 4-methyl esters in overall yields of 50-60\%. Vasi and Desai (1973) prepared 4-methylheptanoic acid from 2-methylbutyric acid using Arndt-Eistert synthesis. Mrowca (1981) reported the synthesis of carboxylic acids or esters by catalytic carboxylation or alcoxycarbonylation of unsaturated hydrocarbons ( 2 was obtained in $86 \%$ yield). More recently, Sonnet and Baillargeon (1989) synthe-

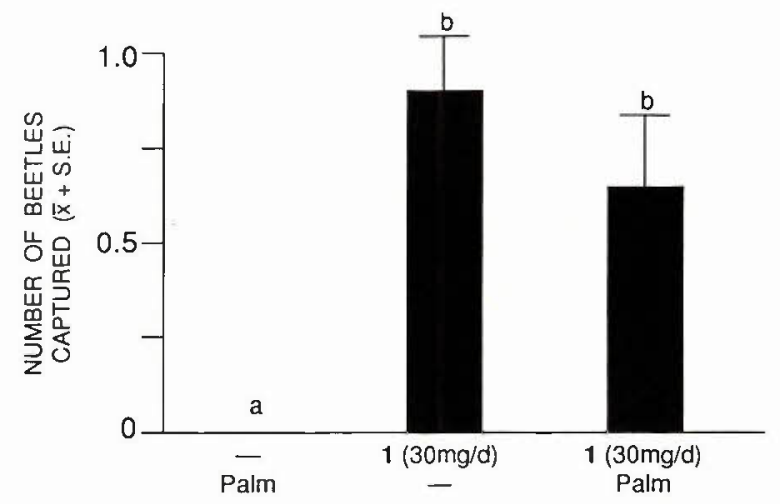

FiG. 5. Attraction of $O$. rhinoceros to ethyl 4-methyloctanoate, 1 (released at $30 \mathrm{mg} /$ day), decaying oil palm tissue, or both together, in pitfall traps at Bah Lias and Rambong Sialang Estates, North Sumatra, Indonesia (October 14-22 and 16-23, 1993, respectively) (experiment 4). Data pooled as no locational differences were found $\left(\chi^{2}=2.2305\right.$, $d f=1, P>0.10$ ). Treatment differences for pooled data, $\chi^{2}=13.036, d f=2, P<$ 0.01 . Bars with the same letter are not significantly different, pairwise $\chi^{2}$ tests, $P<$ 0.05 . 


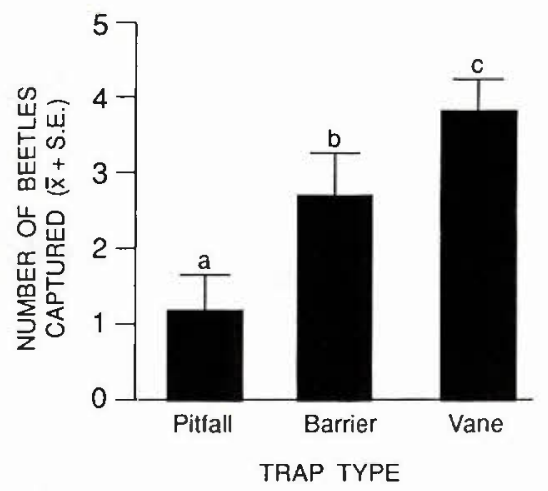

FIG. 6. Efficacy of three insecticide-free trap types for capturing O. rhinoceros (February 2-10, 1994), tested at Rambong Sialang Estate (experiment 5). All traps baited with 1 released at $30 \mathrm{mg} /$ day. ANOVA, $F=6.58$, $d f=2, P=0.007$. Bars with the same letter are not significantly different, Bonferroni $t$ test, $P<0.05$.

sized 4-methyloctanoic acid, 2 , in $53 \%$ overall yield by methylation of the $\mathrm{N}$-t-butylimine derivative of hexanal by condensation with malonic acid and hydrogenation.

In our study, both $\mathbf{1}$ and 3 were prepared by conjugate addition of organocuprates to ethyl acrylate (Corey and Boaz, 1985; Matsuzawa et al., 1989; Perlmutter, 1992; Gries et al., 1994a), a shorter synthetic procedure than in earlier reports. The required cuprates were prepared by adding $10 \mathrm{~mol} \% \mathrm{CuCN}$ to a solution of the corresponding Grignard reagent at $-40^{\circ} \mathrm{C}$. Subsequent addition of trimethylchlorosilane, HMPA, and ethyl acrylate $(2: 2: 1$ ratio) in THF or $\mathrm{Et}_{2} \mathrm{O}$ produced 1 or 3 in $40-55 \%$ yield. Use of $\mathrm{CuBr} \cdot \mathrm{DMS}$ increased the yield of the conjugate addition by $10-15 \%$. No further attempts to optimize the reaction yields were made because $\mathbf{1}$ can also be prepared by the esterification of commercially available 2 (CTC Organics, Atlanta, Georgia).

Syntheses of $\boldsymbol{R}-\mathbf{2}$ and $\boldsymbol{S}-\mathbf{2}$, in high optical purity $(95.4 \%)$ have been reported by Sonnet and Gazzillo (1990). Accordingly, alkylation of hexanoic acid produced 2-methylhexanoic acid, which was reacted with $(R)$ - or $(S)$ - $\alpha$-phenylamine to give diastereoisomeric amides that were separated by crystallization. The optically pure amides were $N$-hydroxylated and reduced to the corresponding 2-methylhexanols, which were oxidized and converted to the methyl 4-methyl2-octanoates via a Wittig reaction with carbomethoxymethylene triphenylphosphorane. Hydrogenation and saponification afforded $\boldsymbol{R}-2$ and $S-2$ in $\sim 10 \%$ overall yield (eight steps).

We envisioned a more efficient route using a highly enantiomerically enriched citronellol (Hanessian et al., 1990; Ho, 1992). The citronellane skel- 


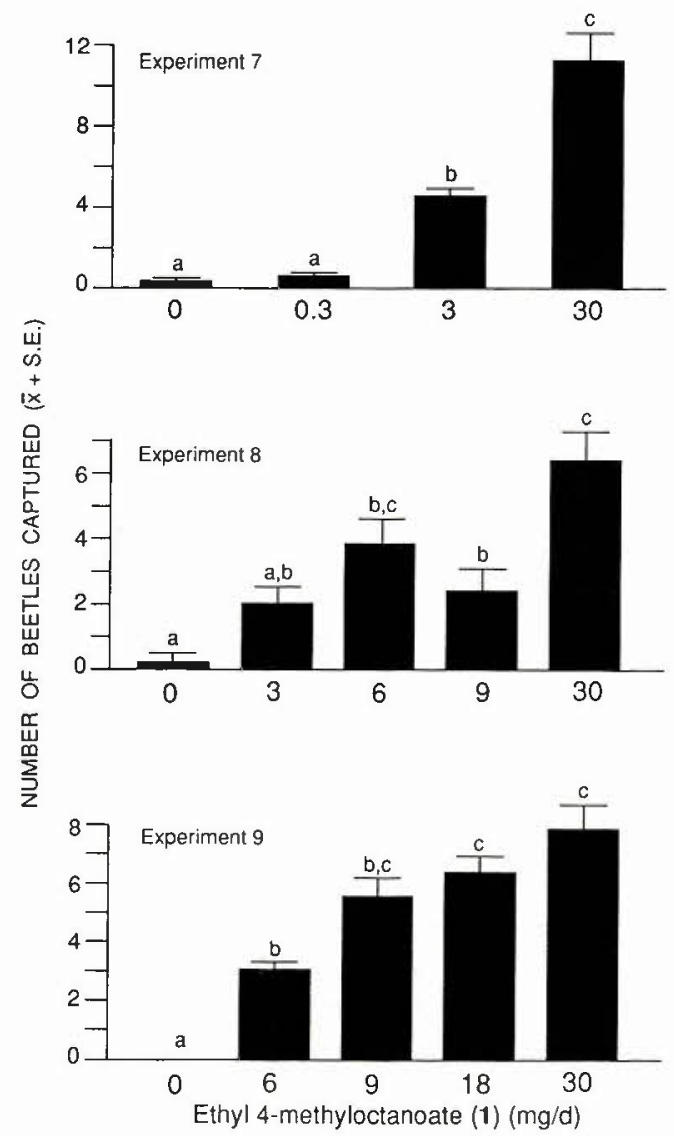

FIG. 7. Attraction of $O$. rhinoceros to 1 released at various rates from standard vane traps. Experiment 7, February 12-26 and February 21-March 4, 1994, Dolok and Rambong Sialang Estates, respectively; ANOVA, $F=44.89, d f=3, P<0.001$. Experiment 8, March 11-17, 1994, Dolok; ANOVA $\log (x+1)$ transformed data, $F=12.13, d f$ $=4, P<0.001$. Experiment 9, May 24-June 8, 1994, Dolok; ANOVA $\log _{10}(x+1)$ transformed data, $F=49.84, d f=4, P<0.001$. Bars with the same letter are not significantly different, Bonferroni $t$ test, $P<0.05$. Untransformed means presented.

eton is commonly used in the synthesis of natural products (e.g., Mori et al., 1991; Stork and Nakamura, 1983; Ho, 1992; Mori and Harashima, 1993a,b; Weinges et al., 1993; Mori and Murata, 1994; Paquette et al., 1995). Modifications at both termini of the citronellane skeleton can be performed without perturbing the chiral center (Ho, 1992). The synthesis of $S-1$ and $R-1$ (Figure 1 , scheme 1) commenced with tosylation of $(R)$ - or $(S)$-citronellol. Chain exten- 


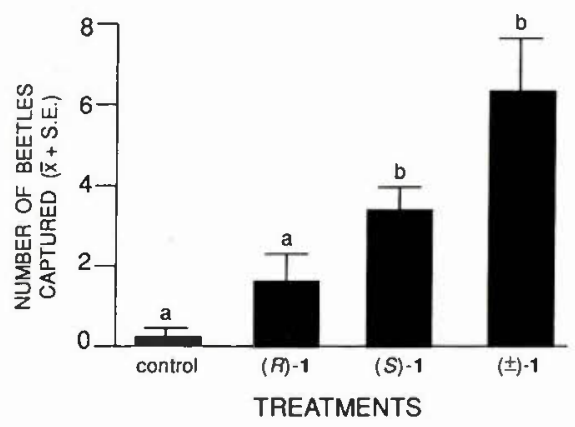

FiG. 8. Attraction of $O$. rhinoceros to standard vane traps containing stereoisomers of 1 at Rambong Sialang Estate (May 23-June 8, 1994) (experiment 10). ANOVA $\log (x$ +1 ) transformed data, $F=24.04, d f=3, P<0.001$. Bars with the same letter are not significantly different, Bonferroni $t$ test, $P<0.05$. Untransformed means presented.

sion via cuprate displacement of the tosylate, 5 (Fouquet and Schlosser, 1974), produced the corresponding 2,6-dimethyl-2-decenes, 6, in high yield. Ozonolysis followed by permanganate oxidation and esterification afforded $S-1$ and $R-1$ in yields of $45-47 \%$ over five steps. Attempts to determine the optical purity of $\mathbf{6}, 7, S-1$, or $R-1$ by gas chromatography using a Cyclodex B column and NMR techniques were unsuccessful. Since the above procedures have significant precedent in the literature and involve transformations remote from the stereogenic carbon, we assumed that the chiral purity of $S-1$ and $R-\mathbf{1}$ was identical to that of citronellol.

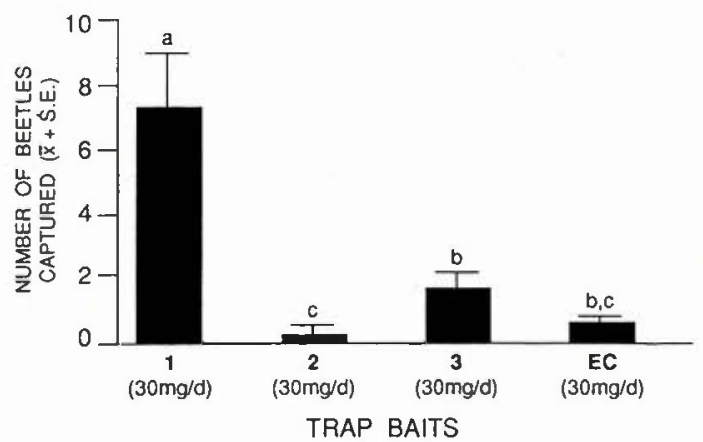

FIG. 9. Attraction of $O$. rhinoceros to $1,2,3$, and $E C$ in standard vane traps at Rambong Sialang Estate (March 30-April 7, 1994) (experiment 11). ANOVA, log $(x+1)$ transformed data, $F=35.77, d f=3, P<0.001$. Bars with the same letter are not significantly different, Bonferroni $t$ test, $P<0.05$. Untransformed means presented. 

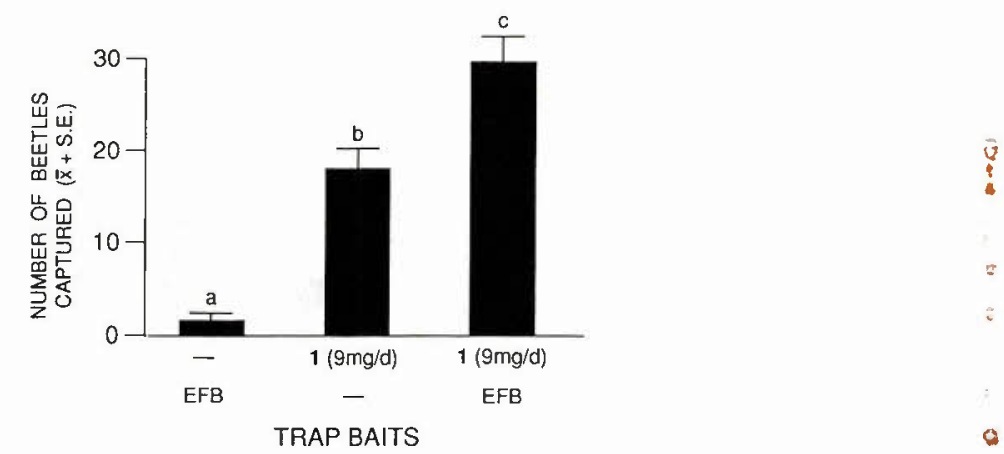

Frg. 10. Attraction of $O$. rhinoceros to standard vane traps containing 1 (released at 9 $\mathrm{mg}$ /day), freshly milled empty fruit bunches (EFB), or both together at Rambong Sialang and Dolok Estates (April 26-May 11 and May 3-18, 1994, respectively) (experiment 14). ANOVA, $F=46.60, d f=2, P<0.001$. Bars with the same letter are not significantly different, Bonferroni $t$ test, $P<0.05$.

Semiochemical communication in $O$. rhinoceros appears to involve both a male-produced aggregation pheromone and a female-produced sex pheromone (Table 1). Because aggregation pheromones have greater potential than sex pheromones for controlling Oryctes populations through mass trapping, research was focused on the identification of aggregation pheromones. Compound $\mathbf{1}$ was confirmed in field experiments as the major male-produced aggregation pheromone of $O$. rhinoceros (Figures 5 and 9). The same compound is a maleproduced aggregation pheromone in the African rhinoceros beetle, $O$. monoceros (Gries et al., 1994a). Other geographically or temporally isolated scarabaeid beetles also utilize identical sex pheromones (Leal et al., 1993a,b).

Oryctes spp. respond to vertical silhouettes (Bedford, 1980). Above-ground light traps with vanes are effective in capturing $O$. elegans in the Arabian peninsula. Superior efficiency of vane and barrier traps for capturing $O$. rhinoceros (Figure 6) may mostly be attributed to the vertical silhouettes that are lacking in the pitfall trap. Because response to the vertical silhouette could not be enhanced further by use of nonreflective black vanes and the use of funnels did not improve retention of captured beetles in traps, insecticide-free, unpainted vane traps were adopted as the standard trap for $O$. rhinoceros.

As in $A$. octiescostata (Leal et al., 1994a), increase of pheromone release rate resulted in increasing numbers of captured beetles. Because traps baited with 1 released at $6,9,18$, or $30 \mathrm{mg} /$ day were similarly attractive, a release rate of $9 \mathrm{mg} /$ day was adopted for operational trapping trials.

In the Japanese beetle, pheromonal attraction is strongly inhibited by the presence of the nonnatural enantiomer of its sex pheromone, $(R, Z)-5$ - 
(1-decenyl)dihydro-2(3H)-furanone (Tumlinson et al., 1977). We therefore investigated the response of $O$. rhinoceros to chiral isomers of 1 . Racemic and $S \mathbf{- 1}$ were similarly attractive to $O$. rhinoceros (Figure 8), indicating that $S \mathbf{- 1}$ is a naturally produced isomer and $\boldsymbol{R}-\mathbf{1}$ is not repellent. Behavioral activity of $\boldsymbol{R}-\mathbf{1}$ and enhanced attraction of $O$. rhinoceros to racemic $\mathbf{1}$ rather than $S$-1 may indicate that both isomers are produced naturally. Accessible racemic $\mathbf{1}$ can be used operationally.

Synergism between aggregation pheromones and host compounds has recently been demonstrated for $A$. octiescostata (Leal et al., 1994d), and palm weevils, Rhynchophorus spp. (Oehlschlager et al., 1992; Gries et al., 1994b; Hallett et al., 1993; Giblin-Davis et al., 1994). Synergistic oil palm volatiles are apparently produced early in the decomposition (fermentation) process because freshly milled fruit bunches but not decomposed palm tissue enhanced pheromone attraction. Investigations are underway to identify palm kairomones and to determine the potential of mass-trapping $O$. rhinoceros in oil palm plantations.

Acknowledgments-This work was supported through an International Development Research Centre Young Canadian Researcher Award and a Natural Sciences and Engineering Research Council (NSERC) Postgraduate Fellowship to R.H.H., and NSERC grants to A.C.O. and J.H.B. The assistance of Dr. R.A. Syed in locating field sites, the generosity of P.T.P.P. London Sumatra Indonesia and its research and technical staff, and the University of Costa Rica for a fellowship to A.L.P. are also gratefully acknowledged.

\section{REFERENCES}

ARn, H., STÄDLER, E., and RausChER, S. 1975. The electroantennographic detector-a selective and sensitive tool in the gas chromatographic analysis of insect pheromones. Z. Naturforsch. $30 \mathrm{c}: 722-725$.

Barber, I.A., McGovern, T.P., Beroza, M., Hoyt, C.P., and Walker, A. 1971. Attractant for the coconut thinoceros beetle. J. Econ. Entomol. 64:1041-1044.

BEDFORD, G.O. 1980. Biology, ecology and control of palm rhinoceros beetles. Annu. Rev. Entomol. 25:309-339

BEDFORD, G.O. 1986. Biological control of the rhinoceros beetle (Oryctes rhinoceros) in the South Pacific by baculovirus. Agric. Ecosyst. Environ. 15:141-147

Burger, B.V., Munro, Z., Roth, M., Spies, H.S.C., Truter, V., Tribe, G.D., and Crewe, R.M. 1983. Composition of the heterogeneous sex attracting secretion of the dung beetle, Kheper lamarcki. Z. Naturforsch. 38c:848-855.

CASON, J., Adams, C.E., BennetT, L.L., and Register, U.D. 1944. Branched-chain fatty acids. III. New method of introducing the branching methyl group. Synthesis of 15-methyloctadecanoic acid and 14-methyltetracosanic acid. J. Am. Chem. Soc. 65:1764-1767.

COREY, E.J., and BOAZ, N.W. 1985. The reaction of combined organocuprate-chlorotrimethylsilane reagents with conjugated carbonyl compounds. Tetrahedron Lett. 1985:6019-6022.

Fouquet, G., and SCHLOSSER, M. 1974. Improved carbon-carbon linking by controlled copper catalysis. Angew. Chem. Int. Ed. 13:82-83. 
Furniss, B.S., Hannaford, A.J., Smith, P.W.G., and Tatchell, A.R. 1989. Vogel's Textbook of Practical Organic Chemistry, 5th ed., Longman, Essex.

Giblin-Davis, R.M., Weissling, T.J., Oehlschlager, A.C., and Gonzalez, L.M. 1994. Field response of Rhynchophorus cruentatus (Coleoptera: Curculionidae) to its aggregation pheromone and fermenting plant volatiles. Fla. Entomol. 77:164-177.

Gressit, J.L. 1953. The coconut rhinoceros beetle (Oryctes rhinoceros) with particular reference to the Palau Islands. Bernice P. Bishop Museum, Honolulu, Hawaii, Bulletin 212.

Gries, G., Gries, R., Perez, A.L., Oehlschlager, A.C., Gonzales, L.M., Pierce, H.D., Jr., Zebeyou, M., and Kolame, B. 1994a. Aggregation pheromone of the African rhinoceros beetle, Oryctes monoceros (Olivier) (Coleoptera: Scarabaeidae). Z. Naturforsch. 49c:363-366.

Gries, G., Gries, R., Perez, A.L., Gonzales, L.M., Pierce, H.D., Jr., Oehlschlager, A.C., Rhainds, M., Zebeyou, M., and Kouame, B. 1994b. Ethyl propionate: Synergistic kairomone for African palm weevil, Rhynchophorus phoenicis L. (Coleoptera: Curculionidae). I. Chem. Ecol. 20:889-897.

Hallett, R.H., Gries, G., Gries, R., Borden, J.H., Czyzewska, E., Oehlschlager, A.C., Pierce, H.D., JR., ANGerilli, N.P.D., and Rauf, A. 1993. Aggregation pheromones of two Asian palm weevils, Rhynchophorus ferrugineus and $R$. vulneratus. Naturwissenschafien 80:328-331.

Hanessian, S., Franco, J., and Larouche, B. 1990. The psychobiological basis of heuristic synthesis planning-man, machine and the chiron approach. Pure Appl. Chem. 62:1887-1910.

Hasegawa, M., LEAL, W.S., and SAWADA, M. 1993. Field evaluation of Anomala schonfeldfi Ohaus (Coleoptera: Scarabaeidae) synthetic sex pheromone. J. Chem. Ecol. 19:1453-1459.

Henzel., R.F., and Lowe, M.D. 1970. Sex attractant of the grass grub beetle. Science 168: 10051006.

Ho, T.-L. 1992. Enantioselective synthesis. Natural products from chiral terpenes. Wiley. New York. pp. 5-16

Ho, C.T., and ToH, P.Y. 1982. Some investigations into the control of Oryctes rhinoceros L. in coconut plantings. Planter 58:492-506.

JACOB, T.K., and BHUMANNAVAR, B.S. 1991. The coconut thinoceros beetle Oryctes rhinoceros L. -its incidence and extent of damage in the Andaman and Nicobar Islands (India). Trop. Pest Manage. 37:80-84.

LEAL, W.S. 1991. (R,Z)-5-(-)-(Oct-1-enyl)oxacyclopentan-2-one, the sex pheromone of the scarab beetle Anomala cuprea. Natumissenschaften 78:521-523.

LEAL, W.S. 1993. (Z)- and (E)-Tetradec-7-en-2-one, a new type of sex pheromone from Oriental beetle. Naturwissenschafien 80:86-87.

Leal, W.S. Sawada, M., and Hasegawa. M. 1993a. The scarab beetle Anomala cuprea utilizes - the sex pheromone of Popillia japonica as a minor component. J. Chem. Ecol. 19:13031313.

Leal, W.L., Sawada, M., and Hasegawa, M. 1993b. The scarab beetle Anomala daimiana utilizes a blend of two other Anomala spp. sex pheromones. Narurwissenschaften 80:181-183.

Leal, W.S., Sawada, M., Matsuyama, S., Kuwahara, Y., and Hasegawa, M. 1993c. Unusual periodicity of sex pheromone production in the large black chafer Holotrichia parallela. $J$. Chem. Ecol. 19:1381-1391.

Leal, W.S., Hasegawa, M., Sawada, M., Ono, M., and Ueda, Y. 1994a. Identification and field evaluation of Anomala octiescostata (Coleoptera: Scarabaeidae) sex pheromone. J. Chem. Ecol. 20:1643-1655.

Leal, W.S., Kawamura, F., and Ono, M. 1994b. The scarab beetle Anomala albopilosa sakishimana utilizes the same sex pheromone blend as a closely related and geographically isolated species, Anomala cuprea. J. Chem. Ecol. 20:1667-1676. 
Leal, W.S., Hasegawa, M., Sawada, M., and Ono, M. 1994c. Sex pheromone of Oriental beetle, Exomala orientalis: Identification and field evaluation. J. Chem. Ecol. 20:1705-1718.

Leal, W.S., ONo, M., Hasegawa, M., and Sawada, M. 1994d. Kairomone from dandelion, Taraxacum officinale, attractant for scarab beetle Anomala octiescostata. J. Chem. Ecol. 20:1697-1704

LIAU, S.S., and AHMAD, A. 1991. The control of Oryctes rhinoceros by clean clearing and its effect on early yield in palm-to-palm replants. Proceedings, PORIM Intemational Palm Oil Congress, September 9-14, 1991, Kuala Lumpur, Malaysia.

LiAU, S.S., and AhMAD, A. 1993. Simulated defoliation and crop loss in young oil palm. Proceedings, PORIM International Palm Oil Congress, September 20-25, 1993, Kuala Lumpur, Malaysia.

Maddison, P.A., Beroza, M., and MCGovern, T.P. 1973. Ethyl chrysanthemumate as an attractant for the coconut rhinoceros beetle. J. Econ. Entomol. 66:591-592.

Matsuzawa, S., Horiguchi, Y., Nakamura, E., and Kuwajima, I. 1989. Chlorosilane-accelerated conjugate addition of catalytic and stoichiometric organocopper reagents. Tetrahedron 45:349362 .

MCCreary, M.D., Lewis, D.W., Wernick, D.L., and Whitesides, G.M. 1974. The determination of enantiomeric purity. J. Am. Chem. Soc. 96:1038-1054.

Minitab. 1989. Release 7.1, Standard Version, Minitab Inc.

MORI, K. 1992. The synthesis of insect pheromones, 1979-1989, in J. ApSimon (ed.). The Total Synthesis of Natural Products, Vol. 9. Wiley, New York.

Mori, K., and Harashima, S. 1993a. Synthesis of $(2 E, 4 E, 6 R, 10 S)-4,6,10$-trimethyl-2,4-tridecadien-7-one-the major component of the sex pheromone of the maritime pine scale (Matsucoccus feytaudi)-and its three stereoisomers. Liebigs Ann. Chem. 1993:391-401.

Mori, K., and Harashima, S. 1993b. Synthesis of $(2 E, 4 E, 6 R, 10 R)-4,6,10-12$-tetramethyl-2,4tridecadien-7-one (matsuone)-the primary component of the sex pheromone of three Matsucoccus pine bast scales-and its antipode. Liebigs Ann. Chem. 1993:993-995.

Mori, K., and Murata, N. 1994. Synthesis of all the eight stereoisomers of methyl 2,6,10trimethyltridecanoate, the male-produced pheromone of stink bugs, Eustichus heros and $E$. obscurus. Leibigs Ann. Chem. 1994:1153-1160.

Mori, K., Harada, H., Zagatti, P., Cork, A., and Hall, D.R. 1991. Synthesis and biological activity of four stereoisomers of 6,10,14-trimethyl-2-pentadecanol, the female-produced sex pheromone of rice moth (Corcyra cephalonica). Leibigs Ann. Chem. 1991:259-267.

MrowCA, J.J. 1981. Acids or esters from unsaturated compounds. Chem. Abst. 95:P97089h.

Oehlschlager, A.C., Pierce, A.M., Pierce, H.D., JR., and Borden, J.H. 1988. Chemical communication in cucujid grain beetles. J. Chem. Ecol. 14:2071-2098.

Oehlschlager, A.C., Pierce, H.D., Jr., Morgan, B., Wimalaratne, P.D.C., Slessor, K.N. King, G.G.S., Gries, G., Gries, R., Borden, J.H., Jiron, L.J., Chinchilla, C.M., and MEXZON, R.G. 1992. Chirality and field activity of rhynchophorol, the aggregation pheromone of the American palm weevil. Naturwissenschaften 79:134-135.

Paquette, L.A., Wang, T.-Z., and Pinard, E. 1995. Total synthesis of natural (t)-acetoxycrenulide. J. Am. Chem. Soc. 117:1455-1456.

Perlmutter, P. 1992. Conjugate Addition Reactions in Organic Synthesis. Pergamon Press, Oxford

PIRKLE, W.H., and SiKKENGA, D.L. 1977. The use of chiral solvating agents for nuclear magnetic resonance determination of enantiomeric purity and absolute configuration of lactones. Consequences of three-point interaction. J. Org. Chem. 42:1370-1374.

Pirkle, W.H., Sikkenga, D.L., and Paulin, M.S. 1977. Nuclear magnetic resonance determinations of enantiomeric composition and absolute configuration of $\gamma$-lactones using chiral $2,2,2$ trifluoro-1-(9-anthryl)ethanol. J. Org. Chem. 42:384-387. 
Sonnet, P.E., and Baillargeon, M.W. 1989. Synthesis and lipase catalyzed hydrolysis of thiolesters of 2-, 3-, and 4-methyloctanoic acids. Lipids 24:434-437.

SonNet, P.E., and Gazzillo, J. 1990. Asymmetric synthesis of 2-, 3-, and 4-methyloctanoic acids. Org. Prep. Proc. Int. 22:203-208.

STILL, W.C., KAHN, M., and MITRA, A. 1978. Rapid chromatographic technique for preparative separations with moderate resolution. J. Org. Chem. 43:2923-2925.

Stork, G., and NAKAmURA, E. 1983. A simplified total synthesis of cytochalasin via intramolecular Diels-Alder reaction. J. Am. Chem. Soc. 105:5510-5512.

TAJudin, M.H., TEOH, C.H., ARIBI, K., and ALI, M. 1993. Zero-buming-an environmentally friendly replanting technique. Proceedings, PORIM International Palm Oil Congress, September 20-25, 1993, Kuala Lumpur, Malaysia.

Tamaki, Y., Sugie, H., and Noguchi, H. 1985. Methyl (Z)-5-tetradecenoate: sex-attractant pheromone of the soybean beetle, Anomala rufocuprea Motschulsky (Coleoptera: Scarabaeidae). Appl. Entomol. Zool. 20:359-361

Tumlinson, J.H., Klein, M.G., Doolittle, R.E., Ladd, T.L., and Proveaux, A.T. 1977. Identification of the female Japanese beetle sex pheromone: Inhibition of male response by an enantiomer. Science 197:789-792.

Valentine, D. JR., Chan, K.K., Scott, C.G., Johnson, K.K., Toth, K., and Sáucy, G. 1976. Direct determination of $R / S$ enantiomers ratios of citronellic acid and related substances by nuclear magnetic resonance spectroscopy and high pressure liquid chromatography. $J$. Org. Chem. 41:62-65.

Vander Meer, R.K., Ghatak, U.R., Alam, S.K., and Chakraborti, P.C. 1979. (土)-Des- $N$ morphinan: A unique bridged hydrocarbon attractant for the rhinoceros beetie, Oryctes rhinoceros, and development of an olfactometer. Environ. Entomol. 8:6-10.

VASI, I.G., and DESAI, K.R. 1973. Optical activity of higher homologous acids prepared from (S)-(+)-2-methylbutyric acid by Andt-Eistert synthesis. Chem. Abst. 78:57621t.

Weinges, K., Ziegler, H.J., Maurer, W., and Schmidbauer, S.B. 1993. Zwei einfache EPCsynthesen mit chemischem beweis der absoluten konfiguration von (+)-mitsugashiwa-lacton aus $(S)-(-)$-citronellol und aucubin. Liebigs Ann. Chem. 1993: 1029-1031.

WOOD, B.J. 1968. Studies on the effect of ground vegetation on infestations of Oryctes rhinoceros (L.) (Col., Dynastidae) in young oil palm replantings in Malaysia. Bull. Entomol. Res. 59:8596.

Young, E.C. 1986. The Rhinoceros Beetle Project: History and review of the research programme. Agric. Ecosyst. Environ. 15:149-166.

ZaR, J.H. 1984. Biostatistical Analysis. Prentice-Hall, Englewood Cliffs, New Jersey.

Zelazny, B. 1979. Loss in coconut yield due to Oryctes rhinoceros damage. FAO Plant Prot. Bull. 27(3):65-70.

ZelazNY, B., and Alfiler, A.R. 1986. Oryctes rhinoceros (Coleoptera: Scarabaeidae) larval abundance and mortality factors in the Philippines. Environ. Entomol. 15:84-87.

ZELAZNY, B., and ALFILER, A.R. 1987. Ecological methods for adult populations of Oryctes rhinoceros (Coleoptera: Scarabaeidae). Ecol. Entomol. 12:227-238.

ZELAZNY, B., and ALFILER, A.R. 1991. Ecology of baculovinus-infected and healthy adults of Oryctes rhinoceros (Coleoptera: Scarabaeidae) on coconut palms in the Philippines. Ecol. Entomol. 16:253-259.

Zhang, A., Facundo, H.T., Robbins, P.S., Linn, C.E., Jr., Hanula, J.L., Villani, M.G., and RoELOFS, W.L. 1994. Identification and synthesis of female sex pheromone of Oriental beetle, Anomala orientalis (Coleoptera: Scarabaeidae). J. Chem. Ecol. 20:2415-2427. 